\title{
Enhancing Pre-service Teachers' concept of Earth Science through an immersion, conceptual museum learning program (Reconceptualising Rocks)
}

\section{Authors}

[Details removed for peer review]

\begin{abstract}
The collaboration between Museum Victoria and ReMSTEP partners: the University of Melbourne and Deakin University has enabled the development of the Reconceptualising Rocks project, designed to enhance the teaching of Earth Science for pre-service Science teachers. This study sought to determine how perceptions and understandings of Earth Science can be enhanced through immersion in the contextual learning in the Museum. Furthermore, the project aimed to explore how science ideas and practices can be translated for educational purposes. The findings revealed that participants found Earth Science interesting and were able to identify links to other Science areas. These findings have implications for the teaching of Earth Science across the curriculum.
\end{abstract}

\section{Introduction}

There has been widespread concern nationally and internationally about the engagement of students with school science and the subsequent uptake of science and technology in the post compulsory years of schooling for some time (Tytler 2007; European Commission 2004). A diminished uptake of student enrolments in pre-service secondary science and technology education courses has contributed to the current shortages of suitably qualified teachers in Australian secondary school subjects of science and technology (Weldon 2015).

Declining student engagement with science has shifted the focus on the need for a change in the quality of science teaching. Much of the impetus for change comes from research findings that students find school science irrelevant and un-engaging due to a prevailing, transmissive pedagogy, and subject content they do not relate to (Goodrum et al. 2001; Lyons 2005).

Tytler (2007) has argued for a re-imagined science curriculum that represents the contemporary practices of science and its links with human endeavours. This position is adopted in the Australian Science Curriculum (ACARA 2012) which has an explicit reform agenda for more inquiry-based teaching and learning of science which emphasises science investigative skills, inquiry, context, contemporary science and its human dimensions.

In response to a report by Professor lan Chubb AC, former Australia's Chief Scientist (Chubb 2012) calling for more funding to support quality teaching in Australian schools, the Australian Government has committed 54 million dollars over four years towards the "Investing in Science and Maths for a Smarter Future' initiative

(http://archive.industry.gov.au/ministerarchive2013/chrisevans/mediareleases/pages/investinginsci enceandmathsforasmarterfuture.aspx.htm). This initiative aims 'to provide more science and mathematics teachers, equipped with better training and better resources, to enter Australia's schools'. One of the programs in this initiative is the Office for Learning and Teaching (OLT) program Enhancing the Training of Mathematics and Science Teachers Programme 
(http://www.olt.gov.au/maths-and-science-teachers), which has sought to drive 'a major improvement in the quality of mathematics and science teachers by supporting new pre-service programs in which faculties, schools or departments of science, mathematics and education collaborate on course design and delivery, combining content and pedagogy so that mathematics and science are taught as dynamic, forward-looking and collaborative human endeavours.' More than twelve million dollars has been allocated for this program which consists of five major projects across Australia; including Reconceptualising Maths and Science Teacher Education Programs (ReMSTEP; funded at 3.2 million dollars). One of the projects within ReMSTEP is the context for this article.

\subsection{ReMSTEP (http://remstep.org.au/)}

ReMSTEP is a three year collaborative project led by the University of Melbourne in association with Deakin, La Trobe and Monash universities. Activities within ReMSTEP are centred on developing new teacher education practices that align contemporary approaches to STEM with engaging teaching and learning. Importance is placed on activities that build collaborative relationships across education and science faculties, universities and specialist science and mathematics centres. These partnerships will drive major improvements in the quality of mathematics and science learning and teaching by creating programs where undergraduate STEM students and pre-service teachers work collaboratively across faculties and specialist centres to create new materials, units of study and expertise in inquiry-based classroom practices. It is this collaboration and embedding of the experience into pre-service programs that are key factors in the successful implementation of REMSTEP. One of the collaborative partnership activities within ReMSTEP is the Reconceptualising Rocks project.

\subsection{Reconceptualising Rocks}

Reconceptualising Rocks is a collaboration of Deakin University, the University of Melbourne and Museum Victoria (http://museumvictoria.com.au/). Museum Victoria is the preeminent source of communicating science to Victorians, based on a legacy of two major public science facilities, Melbourne Museum and Scienceworks. Museum Victoria houses 18 million collection items for science education staff, which includes scientists who research the diversity and origins of the fauna and geology of Australia. Apart from researching the existing collections, the museum has active field programs that further develop the collections. All of the scientists' work leads to research publications, books, websites, apps, museum exhibition and documentaries.

The scientific context for the Reconceptualising Rocks project, as its title suggests, is Geoscience. Pre-service secondary teachers from the University of Melbourne and Deakin University participated in a partnership model whereby students undertook immersion experiences at the Melbourne Museum, one of the three museums incorporated under the umbrella of Museum Victoria, in addition to a field experience. The participants worked with education staff and the resident geologist with the intention of producing curriculum materials to support the teaching of Geoscience as described in the Australian Science Curriculum (ACARA, 2012). Details of the partnership model are given below.

The research literature indicates that Geoscience as a discipline is underrepresented at the postcompulsory years of secondary schooling (King, 2008) but has a strong focus in the Year 8-9 Science Curriculum (ACARA, 2012). It is therefore important for teachers to have content knowledge of 
Geoscience despite often having limited opportunities to undertake Geoscience within their undergraduate Science course.

The prevalence of alternative conceptions in Geoscience has significant implications for the pedagogical approach used in the classroom. Apart from having a strong content knowledge, it is argued that teachers implement inquiry-based approaches (King, 2008) that not only engage students but also develop their scientific thinking.

The Reconceptualising Rocks project has the dual aims of increasing pre-service teachers' understanding of Geoscience processes and the role of scientists in undertaking contemporary Geoscience. In addition, the project aims to find a sustainable partnership model for pre-service teachers to translate science ideas and practices for improving the teaching of Earth Science in secondary schools.

\subsection{Research Questions}

The following research questions are based on a partnership model which connects pre-service teachers to scientists, science research and practice.

1. In what ways does the project enhance pre-service teachers' perceptions of Earth Science and the way Earth Science might be taught in schools?

2. How does the collaboration between Museum Victoria and pre-service teachers translate science ideas and practices for educational purposes in Earth Science?

\section{Literature Review}

\subsection{Earth Science as an Underdeveloped Area of the Curriculum}

Geoscience falls under the umbrella of Earth and space science subjects. Internationally geoscience seems to be increasingly prominent in schools from international survey responses and curricula exemplars. King $(2008,2013,2015)$ has summarized the position of geoscience education worldwide. Currently it is a small, compulsory part of national science and geography curricula and may be available as additional or optional courses. However, Earth and space science subjects are frequently offered to students who are "unmotivated and unable to do "real" science like chemistry and physics' (Lewis, 2008, p. 446). With the exception of Japan, Korea and Taiwan (p. 189), geoscience is largely taught by out-of-field general science teachers (King, 2008; Lewis \& Baker, 2010). Therefore literature cited here will refer to both pre-service and certified teachers.

In Australia, geoscience has been an under-represented subject. From 1976 to 1995, Dekkers and De Laeter (1997) illustrated low enrolments of students interested in geology compared to biology, chemistry and physics when offered at the year 12 level. In the state of Victoria, geology as a year 12 subject ceased to exist after the early 1990's. Although it is still offered in other states, enrolments continue to remain low. The implementation of the Australian Curriculum for years seven to ten in 2014 placed geoscience within Earth and space sciences. This curriculum outlines more specific content descriptions and achievement standards than the previous Victorian Essential Learning Standards (VCAA, 2015a, 2015b). This has created an imperative to more closely examine Earth Science as an area of study. Table I shows the Science Understanding content descriptions for the Earth and space science sub-strand of the Australian Curriculum. At present, geoscience is the focus for years eight to nine. 
Table I - Content Descriptions for Earth and Space Sciences at Years 8-9

\begin{tabular}{|l|l|}
\hline \multicolumn{1}{|c|}{ Year 8 } & \multicolumn{1}{|c|}{ Year 9 } \\
\hline $\begin{array}{l}\text { Sedimentary, igneous and metamorphic } \\
\text { rocks contain minerals and are formed } \\
\text { by processes that occur within Earth over } \\
\text { a variety of timescales }\end{array}$ & $\begin{array}{l}\text { The theory of plate tectonics explains } \\
\text { global patterns of geological activity and } \\
\text { continental movement }\end{array}$ \\
(ACARA, 2014a) & \multicolumn{1}{|c|}{ (ACARA, 2014b) } \\
\hline
\end{tabular}

\subsection{Approaches to Teaching Earth Science}

In this section, some of the approaches to Earth science education will be described and illustrated with examples from the literature. It should be noted that the approaches are not stand-alone and may be integrated throughout the delivery of Earth science units.

\subsubsection{Earth Systems Approach}

In the early 2000's Kali (2003) suggested that Earth science education was characterized by a shift toward a systems approach. This approach integrates sustainability and environmentalism 'somewhat at the expense of the traditional Earth materials, Earth structure, Earth resources and Earth history approach[es] to geoscience curricula' (Vallender, 2010, p. 46). With this in mind 'A Virtual Journey within the Rock Cycle' was developed for Israeli junior and senior high school. In this program, students explored simulated environments that could not be experienced otherwise to learn the parts, connections and system of the rock cycle as a whole.

\subsubsection{Case Based Approach}

Goldsmith (2011) presents a case-based approach promoting student engagement and inquiry in introductory geology classes at the tertiary level. His subject explored essential questions - Where is the world's tallest mountain? - with case studies - Tibet and Iceland. This approach improves students' ability to engage in higher-order thinking, more closely models the scientific method as used in geology while drawing on the curiosity students bring with them into the classroom (p. 119). Goldsmith's students were able to engage with geological concepts and think more deeply about the Earth rather than approaching the subject as a body of facts for 'geologists did not read the theories of plate tectonics, seafloor spreading, or deep time in a book and then go out to apply them to the Earth... [they] explored the earth and used the results... to create theories' (p. 125). Baker (1996) made a similar argument to using the geological approach to understand the environment.

\subsubsection{Inquiry-Based Approach}

Lewis (2008) advises that Earth science teacher education programs should include:

- methods that embrace authentic inquiry;

- state-of-the-art technology and visualization resources;

- $\quad$ strategies for establishing scientific classroom discourse communities and modified instruction (p. 445) 
It should be noted that the term authentic is not used with a consistent meaning in the literature (Houseal et al., 2014, p. 87). In this paper, authentic inquiry means scientific inquiry providing experiential activities engaging students in the synthetic thinking enacted by geologists: 'comparing, connecting and putting together thoughts and perceptions' (Baker, 1996, p. 43). Authentic inquiry could include face-to-face classroom and laboratory activities, online activities or fieldwork.

\subsubsection{Online Approaches}

Online approaches to teaching Earth science can incorporate aspects of those mentioned above, however these digital approaches offer alternative understandings in their use for Earth science teachers and students. According to Feig (2010), networked computing presents opportunities for geoscience instruction innovations. Feig's (2010) study explored the effects of translating an introductory geoscience rock and mineral identification laboratory into an online subject. Statistically comparing the outcomes from a face-to-face group of students with those performing the laboratories online revealed no significant differences. In describing an approach to studying the relationships of rocks and minerals using the social networking site 'Myspace', Kennelly's students found the experience helpful to learn and remember information about rock and mineral samples (2009).

'Google Earth' has been studied in a variety of classroom situations; examples include Blank et al. (2012), Giorgis (2015), Hagevik (2011) and Ratinen and Keinonen (2011). Giorgis (2015) found that students' benefit from using 'Google Earth' to interpret structure depends on their grasp of geological knowledge. Some of the activities involving fault lines in the 'Cyber Enabled Earth Exploration Curriculum' described by Blank et al. (2012) would prove difficult for teachers who do not have a solid grasp on observation of and concepts relating to geological fault lines. In their study of student teachers using 'Google Earth' in problem-based geology learning, Ratinen and Keinonen (2011) found that the pre-service teachers' had inadequate skills to use the technology, interpret maps and analyse the data but they exhibited improved geographical thinking skills.

\subsubsection{The Need for Earth Sciences Pre-Service Teacher Education}

Geoscience is a modern, scientific enterprise in which cutting edge technologies yield evidence about the structure and history of the Earth. It is an engaging science if students are scaffolded to understand the story of geologists' work and its historical interpretive nature. There are five strands that make geoscience a distinct curriculum subject (King, 2008, p. 187):

- the methodologies of geoscience thinking;

- the holistic systems perspective;

- geoscientific spatial abilities;

- the understanding of geological time;

- the methodologies and attributes of geoscientific fieldwork.

The use of inquiry-based approaches 'provide good opportunities for the methods of geoscientific investigation to be included in the curriculum... [but] this will only happen if teachers have strong geoscientific backgrounds which is not the case for most teachers of broad science' (King, 2008, p. 190). Further, the persistent view that Earth and space science can be taught by any science teacher 
points to its low status among the sciences (Lewis, 2008, p. 446) and is 'unsound' (Barba \& Rubba, 1993, p. 280).

The literature on geoscience misconceptions is vast; a few examples include Driver et al. (1994), Francek (2013) and King $(2000,2010,2012)$. Some misconceptions relating to students' understanding of rocks and the rock cycle include understanding Earth's mantle to be solid rather than plastic (King, 2000) and that basalt and granite form from the same magmas (King, 2010). Despite this and other evidence that students do not remember most of the science studied at school, the formal sector has largely ignored these problems in framing curricular content (Stocklmayer et al., 2010, p. 32). In their review of science textbooks as part of Project 2061, Kesidou and Roseman (2002) state that although textbooks are only one resource available, 'many teachers rely on them to provide some or all of their content and pedagogical knowledge' (p. 522). In his survey of 51 textbooks used in England and Wales, King (2010) found that there was not only poor coverage of the National Curriculum but also an average of one error or misconception per page.

In the digital age, textbooks are not the only resources teachers might consult to compliment pedagogical content knowledge of the Earth sciences. Online platforms such as Coursera and EdX offer massively open online courses (MOOCs) for educators and the general public. Some examples include 'Planet Earth... And You!' developed by the University of Illinois at Urbana-Champaign and 'The Dynamic Earth: A Course for Educators' by The American Museum of Natural History.

'Sleuthing Through the Rock Cycle' (Schifman et al., 2013) provides a blended online/offline, constructivist experience for middle and high school students and associated professional development for teachers. This software 'tackles the problems of secondary school teachers' lack of training or comfort teaching Earth science concepts' (p. 268). The web-based resource 'Earthlearningidea' was launched in 2007 to enhance teaching situations in the developing world but proved to be popular world-wide (King et al., 2013). The website provides downloadable activities encompassing a range of approaches to Earth science that can be used by teacher educators and teachers. In 2009 Australian educators used the site so frequently to make it the sixth largest consumer of the material.

Pre-service teachers, however, may not be able to explore these courses and software in addition to their busy teacher training programs. Yet these programs themselves must meet the need to empower future educators with strategies and Earth science appropriate pedagogical approaches. Orion and Thompson (1996) highlight that universities emphasize the theoretical and philosophical aspects of education rather than the concrete practices that pre-service teachers may expect ( $p$. 596). This study proposes that partial immersion programs, such as the 'Reconceptualising Rocks' Project, embedded in pre-service science teacher training may aid in addressing the issues mentioned above and enhance teachers' perceptions of Earth science.

\subsubsection{The Informal Sector's Contribution to Earth Science Teacher Education}

Stocklmayer et al. (2010) present an argument for greater collaboration between the formal and informal sectors. In this paper, the informal sector is defined as settings providing educational experiences outside the school or university. Examples include museums, aquariums, science centres or places traditionally understood as those 'to take students to learn rather than... support the practice of Science teaching' (Kisiel, 2013, p. 83). The informal sector provides apt settings for partial immersion programs pairing scientists with teachers, both pre-service and trained, and students 
seeking to gain an understanding of the nature of science. However the success of these programs is varied.

In schools, doing science conjures images of the laboratory with multi-coloured substances, strange glassware and jars of preserved organisms. The laboratory of geoscience, however, is in the field. Marques et al. (2003) studied Portuguese high school students' perceptions of fieldwork experiences in Earth Science. Over two months, practicing teachers worked with members of the geology/Earth science education team from the University of Aveiro to develop their fieldwork teaching practices focusing on inquiry-based processes. Despite the positive feedback from students, fieldwork experiences served to confirm what had already been studied in the formal setting rather than promoting authentic geological inquiry. This left the students with the perception that fieldwork is not an essential component to geological knowledge. Marques et al. attribute this failure to teachers' lack of confidence implementing new procedures.

Sadler's (2010) review of 53 studies of scientific research experiences from students and teachers reported positive associations with the programs and desired learning outcomes yet participants left these experiences with varying degrees of understanding the nature of science. Varelas et al. (2005) reported that teachers' new scientist identities, developed over a ten week science apprenticeship and research project, were in conflict with what they experienced as teachers.

Earth-View was a three-year professional development opportunity for 45 middle and high school teachers in North Carolina in which participants spent time during summer months documenting geological history and designing research projects while collaborating with colleagues and expert teachers in the field (Dawkins \& Dickerson, 2007). Participants in this study reported a strong content focus and positive, ongoing interactions of support from faculty and colleagues.

The aforementioned studies refer to teachers who are already accredited. At the end of a British post-graduate teacher training program pre-service teachers expressed a lower confidence in outdoor teaching abilities (Orion \& Thompson, 1996). There is room for improvement in teacher training programs to begin scaffolding pre-service teachers in their understanding and delivery of units promoting geoscience inquiry.

Few studies exist describing university-museum collaborations for teacher preparation (Avraamidou, 2014) Studies such as Anderson et al. (2006), Jung and Tonso (2006) and Wallace (2013) are examples of research involving pre-service teachers utilizing the informal sector as teacher training settings. These collaborations have the power to strengthen teacher education programs and provide context where 'theories about teaching and learning are merged with a novel, resource-rich environment' (Gupta \& Adams, 2012, p. 1147). Recent studies indicate that learning to teach science in these settings has potential to influence pre-service teachers' understanding of the connection between conceptual knowledge and inquiry-based pedagogies (Wallace, 2013, p. 814).

These settings also serve to familiarize pre-service teachers with the opportunities available to support the objectives of formal schooling. For example, Kisiel (2013) presents study of pre-service elementary teachers participating in activities and events at museums, aquariums and nature centres. At the end of the study, pre-service teachers shifted their understanding of these places as locations for field trips to institutions that could aid in Science instruction by providing materials or resources and helping them learn content and pedagogy. 
Houseal et al. (2014) suggest that key attributes of successful student-teacher-scientist partnerships include:

- Connecting teachers and students to research science

- Using experiential, research based professional development

- Providing ownership of knowledge by engaging participants to pose and answer their own research questions

With the exception of posing and answering their own research questions, students participating in the Reconceptualising Rocks project were provided with direct experiences of the methods and processes of inquiry used by museum experts. Students were invited to take ownership through task design.

Research into professional development for teachers in geoscience has been limited but 'short courses can be effective in changing the day-to-day teaching of teachers' (King, 2008, p. 192). The Reconceptualising Rocks project provided a short-lived experience in which pre-service teachers were exposed to concepts and task design in Earth science through partnership with Museum Victoria and support from university lecturers and tutors. The following will illustrate how collaboration between teacher training programs and a museum can be employed to complement pre-service teachers' perceptions of and teaching pedagogies related to Earth science. 


\section{Methodology}

The collaboration between the ReMSTEP partners (the University of Melbourne and Deakin University) and Museum Victoria, in particular Author Henry, Manager of Natural Science Collections and Author Gaff, Program Coordinator Life Science, enabled the development of the Reconceptualising Rocks project. The education staff and scientists formed a central focus, with the Museum acting as a contextual setting for the project.

\subsection{Methodology}

The aims of the Reconceptualising Rocks project were to provide an authentic learning experience for pre-service teachers, developing a science specialisation and to connect pre-service teachers to scientists and contemporary science and museum pedagogy practices, while also improving their competence in the teaching of Earth Science.

As previously mentioned, the research questions addressed by the team are:

- In what ways does the project enhance pre-service teachers' perceptions of Earth Science and the way Earth Science might be taught in schools?

- How does the collaboration between Museum Victoria and pre-service teachers translate science ideas and practices for educational purposes in Earth Science?

The Learning Experience Model used in the Reconceptualising Rocks project is presented in Figure 1.

\subsubsection{Learning Experience Model for the Reconceptualising Rocks project}

The model presented below was used to illustrate learning experience for pre-service teachers:

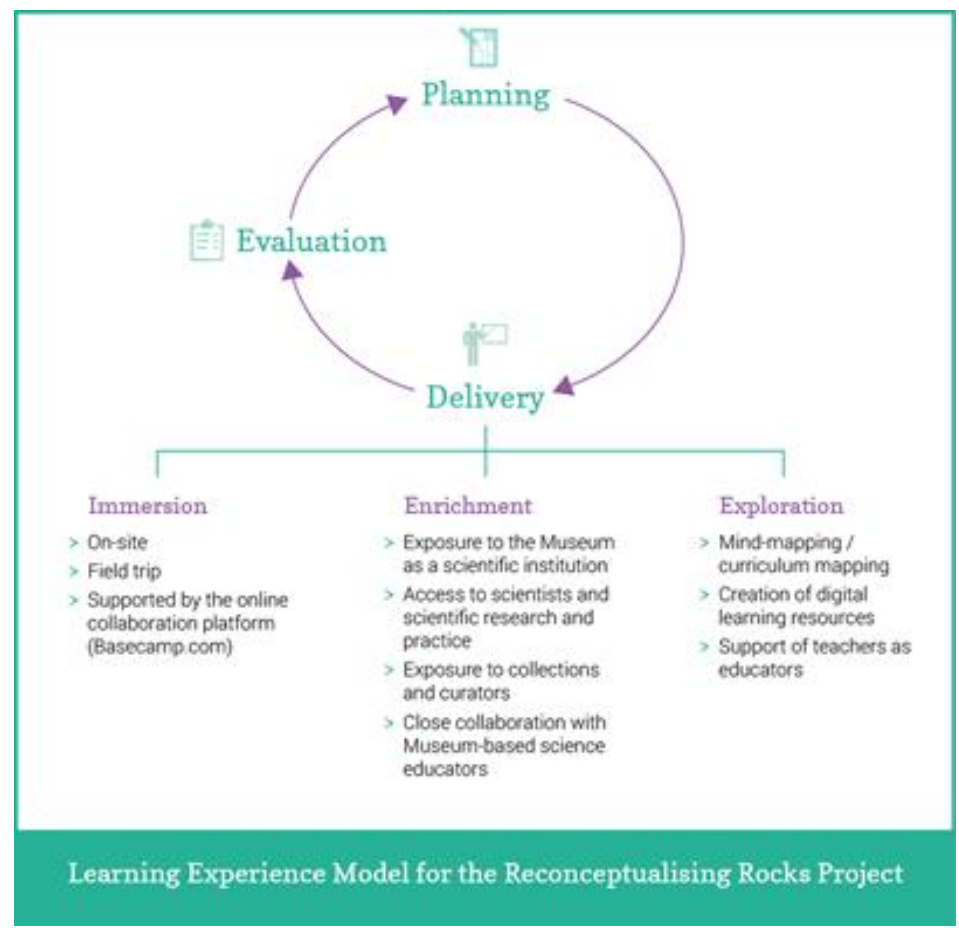

Figure 1 - Learning Experience Model the Reconceptualising Rocks project 


\subsubsection{Project Planning}

Links to the Victorian Curriculum, AusVELS and the Australian Curriculum Science Strands: Science Understanding (SU), Science as a Human Endeavour (SHE) and Science Inquiry Skills (SIS) were considered in the planning of the project.

\subsubsection{Selection of participants}

The Reconceptualising Rocks project was offered to all Master of Teaching (Science) pre-service teachers at the University of Melbourne and interested candidates were invited to send an Expression of Interest (Appendix 1). At Deakin University, the project was promoted as relevant not only for pre-service teachers, but also for students considering taking up other careers. This was to encourage teaching as a career alternative for those who may not have considered this previously (ReMSTEP Outcome 2, Appendix 2).

Nine pre-service teachers from the University of Melbourne and eight Bachelor of Science students from Deakin University, five of whom were also pre-service teachers, participated in this study.

Throughout the project, participants were encouraged to:

- collect specimens whilst in the field;

- photograph field sites, or exhibition, or specimens in the collection;

- learn about the geology of the area;

to produce a digital resource which would be hosted on the Basecamp.com online collaboration platform, ReMSTEP and Museum Victoria websites.

The pre-service teachers from the University of Melbourne were also required to develop a lesson plan relating to an area of the Victorian Curriculum Level 8 Earth and Space Sciences Curriculum, connected to their digital resource, and to be made available to other science teachers through the Museum's online resources.

\subsubsection{Project Delivery}

The focus of the project was an exploration of the pedagogical approaches of teaching Earth Science, rather than on delivering content knowledge. Participants were encouraged to view Geology as a forensic science, underpinned by the fundamentals of Physics, Chemistry, Mathematics and Biology. By engaging in the project, participants gained an understanding of the importance and relevance of geological sciences.

The delivery involved three separate components; immersion, enrichment and exploration.

\subsubsection{Immersion: Museum workshops and the field trip}

Participants spent two full days at Museum Victoria, followed by a field trip to Phillip Island where they were immersed in the practical and evolutionary aspects of the formation and classification of rocks.

Day One consisted of learning about the museum and its education program. A lecture and guided tour of the Dynamic Earth gallery by the museum's geologist and an activity experienced as a Year 8 student undertaking the Rocks-Camera-Action education program. This enabled the participants to reflect on what they already knew, what they had learnt and how their understanding of Earth Science had changed over the course of the day. 
Day Two consisted of a back of house tour of the Mineral and Rock collection. During this time, participants were introduced to the scientific research behind the exhibitions and communicated with the scientists working at the Museum.

Phillip Island was selected for the full day field trip because it is a microcosm of Victorian geology. Exposed on the island is a diverse range of igneous, metamorphic and sedimentary rock types, which traverse the range from the oldest Victorian rocks, formed in the Cambrian ( 550 million years) through to the youngest Quaternary rocks ( $\sim 10000$ years).

The main location near Kitty Miller Bay was selected because it provided an opportunity to discuss a range of concepts and processes such as; geological time, unconformable rocks sequences, volcanism, metamorphism, erosion, the rock cycle, sea-level changes and the composition of the beach sands. Students were also challenged to visualise what the landscape would have been like in the past.

Unconformities, time sequences and erosion were observed at Pyramid Rock where 360 million year old granite was overlain by relatively young volcanic rock (approximately 22 million years in age).

At the Colonnade's, columnar jointing and weathering features in 22 million-year old basalts were identified from the cooling of lava and erosional processes.

Before the field trip, pre-service teachers were presented with a number of key themes relating to changes in the environment, rock diversity and types, erosion, life cycle of rocks and Science as a Human Endeavour, which were required to be embedded in videos, notes and other materials produced on the field trip. These themes also played a part in enriching the concept maps preservice teachers were producing throughout the Program.

Examples of some of the themes are provided below.

\section{Change over time}

The landscape you are looking at formed over many millions of years. How it looks today is not how it looked in the past, nor how it might look in the future. How can the rocks tell us about the change that has taken place over time?

\section{Life cycle of a pebble/rock}

Find a greenstone pebble on the beach. How did it first form? How has it changed over time? What forces have acted on it to change it? What could happen to it?

\section{Erosion and weathering}

Erosion and weathering are important processes in the formation of sedimentary rocks. What types of weathering and erosion can you see at this site? What impacts are they having?

\section{Rock diversity and rock types}

At this site, you will find a number of different rock types. How did those rocks form? Why might there be multiple rock types within one area? 


\section{Science as a Human Endeavour - the green rock story}

Museums often rely on information from the public to enhance our understanding of the world around us. Citizens will often contact the museum to let us know that they have found something interesting, everything from possible new fossil finds, whales washed up on the beach to new rocks types. Investigate how Science knowledge can develop through collaboration and connecting ideas across the disciplines of science.

Over a number of carefully selected locations, teacher candidates collected specimens and observed rock diversity and formation. Some of rocks found and identified include the basalt and a number of pyroclastic or volcaniclastic rocks deposited like sediments, however igneous in origin. Author Henry's expert commentary at each location and short stories around key features of the landscape provided insight into the fascinating world of Earth Science.

Following the field trip, pre-service teachers produced short videos about their experience at Phillip Island. One of the criteria for this assessment was that other science teachers could use the material. Lesson plans were produced to accompany the videos.

\subsubsection{Enrichment}

Museum Victoria played a key role in the Reconceptualising Rocks project, by connecting participants with contemporary museum and scientific practices. Access to science collections and current pedagogical approaches supported the participants in developing their understanding of innovative and engaging approaches to teaching Earth Science. Museum Victoria, as a contextual setting, also provided enriching teaching materials and contemporary scientific approaches.

\subsubsection{Exploration of pedagogical approaches to teaching and learning}

Pedagogical approaches modelled by the project team included; mind-mapping activities, the development of digital learning resources, unit planning and lesson development. Pre-service teachers observed that adding to their mind maps over the course of the program enabled them to connect between various elements; in particular the gaps in the detail of their initial mind maps. The process of commencing this task, prior to knowledge building activities in the Museum galleries allowed pre-service teachers to develop their prior knowledge of Earth Sciences.

Commencing their mind mapping activity, pre-service teachers observed that 'they don't have a lot to put down [on paper] yet'. One participant also commented 'It's a bit daunting to be expressing your knowledge about Earth Sciences at this early stage.

As the process unfolded, pre-service teachers commented that the information presented in the galleries gave them a new outlook on Earth Sciences, helping them to see how much rocks and minerals affect our everyday lives. One pre-service teacher was surprised at the extent of that 'random minerals were used as household objects'. Explanations of 'how the rocks formed' were very insightful. Without the expert commentary of the expert facilitator, Author, 'it could be a bit hard to read the signs'. The passion, enthusiasm and depth of knowledge that Author provided, were key factors in enhancing pre-service teachers' interest and enrichment of the final version of their mind maps. 


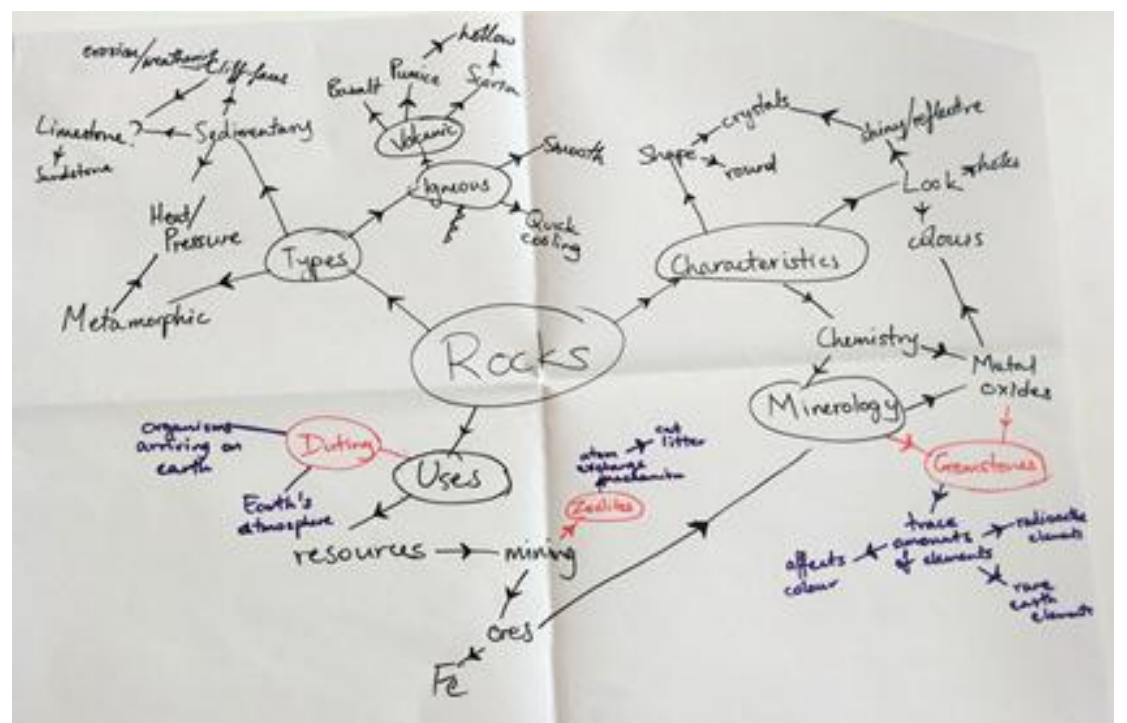

Figure 2 - Example of one pre-service teacher's mind map

The pedagogical practices employed by the museum education staff were included as part of the Reconceptualising Rocks project delivery to provide participants with opportunities to explore and enhance student understanding of Earth Science.

\subsubsection{Project feedback and evaluation}

The impact of the Reconceptualising Rocks project, feedback and reflections from the participants and the project team were evaluated to provide evidence of the effect of the project on pre-service teachers' understanding of scientific practices in Earth Science. As previously noted, these goals align with ReMSTEP Outcomes 1 and 3 (see Appendix B).

\subsubsection{Human Ethics}

An application for Human Ethics was made to the Human Research Ethics Committee of each university and was subsequently approved on March $19^{\text {th }}, 2015$. Informed consent was given by the participants from each university. Care was taken to ensure the anonymity of participant responses.

\subsubsection{Data collection}

To investigate the ways the Reconceptualising Rocks project enhanced pre-service teachers' perceptions of Earth Science and the way the support provided by the Museum Victoria translated science ideas and practice for teaching in schools, a variety of research instruments were used. These included a pre-service teacher survey, a focus group discussion and a series of project team interviews. Table 2 presents the questions asked in the survey.

Table 2 - Survey Questions

\begin{tabular}{|c|l|}
\hline 1 & What expectations did you have of this project before you commenced it? \\
\hline 2 & $\begin{array}{l}\text { What were the major differences between your expectations of the project and the } \\
\text { reality? }\end{array}$ \\
\hline
\end{tabular}




\begin{tabular}{|c|l|}
\hline 3 & $\begin{array}{l}\text { How have your perceptions of the relevance of Earth Science in the secondary science } \\
\text { curriculum changed through your participation in this project? }\end{array}$ \\
\hline 4 & $\begin{array}{l}\text { What elements of the project do you believe have contributed to your capacity to } \\
\text { provide quality Earth Science education? }\end{array}$ \\
\hline
\end{tabular}

The survey was given to pre-service teachers during the field trip to Phillip Island and prior to their final session at the Museum. All of the participants from the University of Melbourne completed the survey.

During the field trip, a member of the project team conducted a focus group discussion with 15 preservice teachers from Deakin University and the University of Melbourne. Table 3 presents the questions asked during the discussion.

Table 3 - Focus Group Questions

\begin{tabular}{|c|l|}
\hline 1 & $\begin{array}{l}\text { What understandings do you now have, that you didn't have before, about the role of } \\
\text { scientists in the museum and the role of the museum to support contemporary science? }\end{array}$ \\
\hline 2 & $\begin{array}{l}\text { What scientific practices carried out in the Museum have you learnt about that surprised } \\
\text { or impressed you? }\end{array}$ \\
\hline 3 & $\begin{array}{l}\text { How has working with scientists from the Museum shifted your understanding of science } \\
\text { and/or learning? }\end{array}$ \\
\hline 4 & $\begin{array}{l}\text { Has your understanding of contemporary Earth Sciences changed as a result of this } \\
\text { project? If so, how? }\end{array}$ \\
\hline 5 & $\begin{array}{l}\text { How have your perceptions of the relevance of Earth Science in the secondary science } \\
\text { curriculum changed through your participation in this project? }\end{array}$ \\
\hline 6 & $\begin{array}{l}\text { Would the process of the development and production of the digital learning resource } \\
\text { be applicable in the classroom situation? Would you use this process in your own } \\
\text { teaching? }\end{array}$ \\
\hline
\end{tabular}

The focus group discussion held at Phillip Island on March 21 1 , 2015, was video recorded and later transcribed in preparation for analysis. The duration of the discussion was 20 minutes. 
The third research instrument involved three separate interviews at the conclusion of the project between a ReMSTEP team member; academic staff involved in the project and key Museum facilitators. The same REMSTEP team member directed the three interviews, which were conducted at Deakin University, the University of Melbourne and the Melbourne Museum. The interviews varied between 20 minutes and 54 minutes in length, were audiotaped and later transcribed.

Table 4 presents the questions posed to the project team relating to the project's impact on students' knowledge, skills and attitudes, including pedagogical expertise and the role of the museum.

Table 4 - Team Interviews

Project's impact on students' knowledge, skills and attitudes, including pedagogical expertise

\begin{tabular}{|c|c|}
\hline 1 & What are your overall impressions of the project? \\
\hline 2 & Were your expectations aligned with the project's outcomes? \\
\hline 3 & $\begin{array}{l}\text { In what way was the collaboration with the project team useful for you and the pre- } \\
\text { service teachers? }\end{array}$ \\
\hline 4 & $\begin{array}{l}\text { Could pre-service teachers have achieved the same outcome without taking part in this } \\
\text { project? }\end{array}$ \\
\hline 5 & What was the most valuable aspect of the project for you and the pre-service teachers? \\
\hline \multicolumn{2}{|c|}{ The role of the museum } \\
\hline 1 & $\begin{array}{l}\text { What understandings do you now have, that you didn't have before, about the role of } \\
\text { scientists in the museum and the role of the Museum to support contemporary science? }\end{array}$ \\
\hline 2 & What scientific practices carried out at the Museum surprised or impressed you? \\
\hline 3 & $\begin{array}{l}\text { What insights have you gained from this project in relation to translating contemporary } \\
\text { science ideas for educational purposes? }\end{array}$ \\
\hline 4 & $\begin{array}{l}\text { What could secondary school students learn about contemporary science practices } \\
\text { through visiting the Museum? }\end{array}$ \\
\hline
\end{tabular}




\section{Analysis}

An inductive approach to thematic analysis was used to identify patterns, or themes within the collected data (Author, 2015) [details removed for peer review]. The themes emerged directly from the data, using two diverse yet complementary approaches.

Two members of the project team performed the analysis of the transcribed data separately. QSR NVivo and manual coding were used to identify the common themes. QSR NVivo allowed for effective sorting, classification and deep levels of analysis of project data, including text-based and multimedia sources. Search, query and visualisation tools were used to determine the connections and patterns in the data.

\subsection{Themes}

The following terminology has been used to distinguish the origin of the comment:

- Survey - participant's survey response

- Focus Group - participant's focus group comment

- PT - members of the project team's comment

\subsubsection{RQ1 - Perceptions of Earth Science and its pedagogy}

Participants regarding their expectations and experiences of the project reported several themes. Some participants expected that the project would not only increase their content knowledge of Earth Sciences but also provide specific teaching approaches for implementation in their classrooms.

\subsubsection{Interesting and engaging}

In contrast to some of their secondary school experiences, participants' engagement and interest in Earth Science was evident throughout the project. The Reconceptualising Rocks project has been shown to have ignited participants' enthusiasm and anticipation in teaching Earth Sciences. In particular, one student stated that 'all science students would benefit from learning Earth Science'. Other responses included:

I found earth science not as interesting as other science areas during my secondary school experience. However, this program allowed me to understand how interesting Earth Science can be when presented by passionate and knowledgeable individuals.

(Survey)

This program revealed that Earth Sciences can be much more engaging and relevant than I ever imagined. I feel much more prepared and excited about approaching Earth Science in my teaching.

(Survey)

We spent a lot of time actually interacting with specimens compared to actual learning in a lecture style.

(Survey)

Some of the participants expressed appreciation at the depth of knowledge and dedication of the Museum staff. Participants commented that the staff were helpful and that the museum was a useful resource. 
After being involved in the project I was pleasantly surprised at how engaging and interesting I found the content. It was really enjoyable to work with such highly regarded individuals from the museum.

(Survey)

I have always had an interest in Earth Sciences but had never learnt about it at such an in depth level. I not only found it interesting but I also found it to be quite educative and informative, and I think that all science students would benefit from learning Earth Sciences.

(Survey)

Overall, the expertise of the museum staff and the learning context setting at the Museum, with its access to authentic artefacts, rich array of specimens and curated information were highly valued by the participants.

\subsubsection{Links to other areas of science}

A number of links were made to areas such as History, Palaeontology, Ecology, Physics, Geophysics, Geography, Meteorology, Geology, Sedimentology, Climatology and Chemistry. Certain areas such as Meteorology were covered in some detail during the guided tours of the Earth Science galleries at the Museum by the resident Geologist and member of the Reconceptualising Rocks project team, Author Henry. Participants were given an overview of the origin and nature of rock specimens. The learning was further supported by additional resources provided by the online support platform Basecamp.com.

I have realised how important Earth Science is in linking other methods of Science together as well as other areas of study, such as history. The three days provided me with ideas and a different view that I could possibly make relevant in a classroom situation in years to come.

(Survey)

I can see the importance of Earth Science to many other areas of Science. I am now able to link in ideas from Chemistry and Physics and apply them to geological concepts.

(Survey)

I see now that it has much more relevance than I first thought. I had never considered its application to an astronomy unit as well and the local resources that can be used.

(Survey)

Participants found the Reconceptualising Rocks project to be beneficial in addressing some of their preconceived ideas about the nature of Earth Science:

I expected it to just be about old rocks and a lot of teaching about rock research in terms of fossils. I had no idea really about mineral research or even considering meteorites in the same category of 'geology'.

(Survey)

\subsubsection{Earth Science is evolving}

A theme of dynamically evolving landscapes and their characteristics was mentioned during the guided visits to the galleries at the Melbourne Museum and the field trip to Phillip Island. Fossils embedded in the landscape tell a compelling story of its evolution. Project participants found this topic fascinating. 
In particular, two participants commented that Earth Science is dynamic and changing:

Earth Science is still an ongoing research area so what has stuck with me is in the palaeontology bit we were talking about at the dig site at Inverloch. There's somewhere right at my doorstep that they're still digging and finding fossils and taking fossils and examining those and understanding what happened in Australia from those fossils. So there's still contemporary research going on and current research happening in Victoria which is really important to highlight to students. To tell them that science isn't just something that old Copernicus and Galileo did back in the 1600s. It's actually something they're doing in 2015 at the beach down the road. I think it's really important for kids to realise that.

(Focus Group)

Before I always thought when they talk about Geology or Earth Science it's like something happened millions of years ago and it's not like it's going to change for a long time for centuries like theoretical physics... I just realise Earth Science it quite dynamic and it's changing all the time.

(Focus Group)

Another participant acknowledged the importance of the evolution of Earth Science by comparing "teaching from a text book" to teaching with contemporary scientific practices - "something that is constantly evolving and adapting".

I was reading about the notion of teachers teaching science as though it's facts and staid, and perhaps that's related to it if you look at a book and if you're teaching from a text book, then it's going to seem very much staying in one position, as opposed to it being something that's constantly evolving and adapting.

The idea that rocks are just part of the clues that unravel a puzzle also resonated with a member of the project team who stated:

It's about getting students to think beyond the Geology or boring rocks or whatever, and the rocks are just part of the clues to unravel what the processes were in a sense.

(PT)

\subsubsection{The importance of Earth Science}

According to the review of the literature previously referred to in this article, Earth Science (including Geoscience) is seen as an underdeveloped area of the curriculum. The importance of this area and ways of teaching concepts such as the rock cycle, earthquakes and soil formation must be integrated into pedagogical approaches to help students learn. Participants affirmed their ideas about the place of Earth Science in the curriculum:

My participation in the project has validated and further supported my prior perception of the importance of Earth Science in secondary schools.

(Survey)

I already thought of Geology as an important part of Science so this was more confirmed than anything.

(Survey) 


\subsubsection{RQ2 - role of the Museum to translate ideas into practice}

Participants appreciated the opportunity to be shown around the exhibits and get an overview of the Earth Science collections by an expert. The recognition of the research carried out by scientists was also acknowledged and appreciated.

I never really looked at museums as being centres for research (I blame Night at the Museum).

(Survey)

Having experts talk to us - giving us basic and more detailed explanations when necessary, was a highlight of the programme.

(Survey)

\subsubsection{Practical and hands on}

The Reconceptualising Rocks project was mentioned by the participants as being a practical and hands on experience. Exploring a complex topic in this way generated a significant amount of interest and enthusiasm which was appreciated, especially considering their previous limited knowledge in this area.

The hands on aspect of the project has made it so much more valuable because of the interest it has created that I can then pass on.

(Survey)

I feel that it would be difficult to teach students the wonder of geology without being able to offer hands on experience.

(Survey)

An ability to explore the museum collections in detail enabled participants to explore ways of integrating the concepts into their teaching.

One of the major elements was actually viewing the collections and being able to hold the various rocks which kept the topic interesting.

(Survey)

\subsubsection{Insight into the role of the Museum and using it as a resource for teaching science}

A number of insights into the role of the museum have emerged through the analysis of the interviews with the project team and the focus group. These included clarifying some of the common misconceptions such as the museum being viewed simply as a 'cabinet of curiosities'. These conversations have been instrumental in transferring participants' perceptions about museums and their central role in connecting research and practice, especially in secondary Science education.

A lot of teachers (and pre-service teachers) don't realise that we are a scientific institution and look after the state's natural history collection and also undertake research. We're not just a cabinet of curiosities, and that what they can do as future teachers is to think more deeply about the notion of what is a museum, whether they are coming here for Geology or any other area of the curriculum and how might they get their students to engage (with the museum). 
One of the advantages of holding the project at the museum was the availability of Earth Science resources and access to scientists. The participants also viewed the Museum as an opportunity for improving their knowledge and approaches to teaching:

The Museum has a fundamental role and it can supply and educate us. As teachers it can educate us. It's not just going to a textbook. It's not just going to a professor at the university. But it's also that I can go to the museum.

(Survey)

\subsubsection{Communication of science ideas and practices}

Participants have noted a number of novel ways that science ideas can be communicated, either through the use of media (in this case an interactive immersive volcano experience at the museum) or through the scaffolding and the transfer of scientific knowledge into an appropriate language.

What I really liked in the museum was the interactive - the cinema, it comes out at you and it takes you around. You actually then see it not just in books but you're seeing it there and you feel like you're there and it's taking you over the land and into the volcano and you see the lava flowing. That was amazing. So for me that was a brilliant learning experience.

(Focus Group)

Some people are extremely good at understanding and breaking down (science) language and I think that's one of the challenges is that other people don't know that certain vocabulary and it can be like speaking another language to people. So it's a good thing to think about. Then how do you try and build that understanding...

(PT)

\subsubsection{Field trips}

The field trip to Phillip Island was a highlight of the program. Most participants commented on the breadth and depth of geological samples and landscape features available through the trip and the way they were expertly guided through the most interesting geology of the island.

The field trip was fantastic in revealing the presence of important geological examples in the local environment. It was great to see how this concept could be translated into any geological sites around the area local to a secondary school.

(Survey)

The importance of Phillip Island as a site enabled the translation of practical examples into teaching ideas.

I found that even a relatively small place (like Phillip Island) can reveal a variety of geologic processes. I think of rock diversity as being as varied as biological diversity now.

(Survey)

The field trip was very insightful because I now know real life examples which are local to use and explain to students.

(Survey)

Participants were sensitive to the amount of thought and planning required and the investment of time and money for schools in organising a field trip. 
I feel that the time in the museum is the part of the program that is most transferrable to the classroom. Whist the field trip was a wonderful experience and would be a great learning experience for students, the practicality of delivering this as part of the curriculum may not always be possible.

(Survey)

\subsubsection{Transfer of practices for educational purposes}

The use of activities such as Rocks-Camera-Action, described earlier in this article, provided the participants with engaging learning experiences to use with their classes:

There was more of an emphasis on how rocks can form through the cycle than I had expected. I did not expect the short video project on the first day. I enjoyed that and can see myself using that technique to engage students in Earth Sciences.

(Survey)

The movie making experience was excellent and potentially enjoyable for students as well. (Survey) 


\section{Discussion and Conclusion}

In 2014, Melbourne Museum hosted 135,000 school excursions. Teachers play a crucial role in the learning experience that those students encounter whilst on an excursion to the museum. However, this relies on the teacher being familiar with the museum and best practice in museum pedagogy. Despite the museum offering such programs, practising and pre-service teachers often do not have the opportunity to be involved in a contextual learning program. Whilst Orion and Thompson (1996) argue that universities emphasise the theoretical and philosophical aspects of education this partnership program that is embedded in the courses the pre-service teachers undertake provide more of the concrete practices that the pre-service teachers may expect in teaching in schools.

Stocklmayer et al (2010) and Kisiel (2013) present an argument for greater collaboration between the formal and informal sectors as an important factor to enhance learning outcomes for students engaged in informal learning programs. Within this program there was a strong collaboration between the universities that involved the teacher educators at the University of Melbourne, Deakin University and the Melbourne Museum. The program arose from several planning meetings between all parties to ensure mutual benefits for all and that the museum experiences were embedded within the pre-service teacher programs. The collaboration between the universities and the museum provided a rich learning environment in which scientific content knowledge; curriculum knowledge, pedagogical practices and approaches could be addressed. Collaboration might be seen as a critical factor for the success of a program given varied success of partnership programs in the literature (Sadler et al., 2010).

The program addressed a call for geoscience as a modern, cutting edge science enterprise to be included in pre-service teacher education through what King (2008) advocated as inquiry-based approaches that provide insights into the methods of geoscientific investigation. This was achieved through engagement with museum scientists and the development of original teaching resources that addressed the Earth Science curriculum. Through the program the pre-service teachers gained insights into the rich area of geoscience misconceptions (Driver et al., 1994; Francek, 2013) and how to address these from an inquiry-based perspective, in the classroom. These insights informed the development of pre-service teachers' curriculum resource.

The findings from this study are the first step in a wider research on contextual Earth Science learning at the Museum for pre-service science teachers. As the project is reviewed and revised, further data will be collected and analysed. In particular, the expertise and support of the museum educator and resident Geologist in collaboration with the university teacher educators increased the confidence of the participants and provided them with pedagogical practices to be used in their future classrooms.

Pre-service teachers will always be expected to teach across many areas of the science curriculum, despite having an expertise developed in one or two areas - such as Biology or Chemistry. In Australia, $75 \%$ of secondary science teachers have never studied geology at a tertiary level (Harris et. al., 2005). Yet, research shows that "it is widely recognised that teachers need to be well-versed in the subjects they teach to be adept at optimizing learning" (Andreas, 2011). There will always be a need for the pre-service teachers to develop skills, confidence and knowledge in other areas of the curriculum and of course in the area of Science as a Human Endeavour. Museums, as places of lifelong learning, scientific research and education can play a crucial role in supporting the preservice teachers in areas of the curriculum like Earth Science, and help make connections not only to 
content but also to authentic scientific approaches and innovative ways in which to embed those in science teaching.

The overall aims of this study were to determine whether the Reconceptualising Rocks project might enhance participants' perceptions and understandings of Earth Science and how the science ideas and practices can be translated for educational purposes. Participant' views indicated that the project has provided a new and exciting approach to their understanding of Earth Science and the methods they will use to enhance their own students' understanding of this important area of Science.

The involvement of the staff from Museum Victoria and their expertise in providing both geological knowledge and pedagogical approaches has been instrumental for the development of scientific content knowledge and curriculum ideas for the pre-service teachers in the program. The voices of the participants and the project team reveal the value of the settings, at the museum and at Phillip Island, to the immersive experience of the contextual science learning.

The research findings also provide evidence of the importance of collaborations between universities and museums in the development of pre-service teachers' pedagogical content knowledge. This study contributes to limited studies that describe university-museum collaborations for teacher preparation (Avraamidou, 2014) and show that such collaborations have the power to strengthen teacher education programs (Gupta \& Adams, 2012). 


\section{Limitations of the study}

Due to the nature of the project the number of participants was limited to 17 . The findings presented in this article arose from the analysis of the first phase of the Reconceptualising Rocks project (March 2015). The project was repeated in July-August, 2015. As yet, no comparisons have been drawn between the findings of the two phases.

This research has triangulated data collected from surveys, focus group discussions and interviews with the project team and pre-service teachers. The duration of the focus group discussion was brief and not all participants in the focus group discussion presented their responses to the seven questions asked. At this stage, the digital resources and other products of this program have not been included in the data, due to permission not being sought of participants.

\section{Implications for further research}

The participants in the Reconceptualising Rocks project were assessed according to the guidelines agreed upon by each of the collaborating universities. Data analysis could investigate the relationship between participants' assessed work (digital learning resources) and their perceptions of the project.

The following questions provide direction for future research:

- Could the current Learning Experience Model, as presented in Figure 1 be applied to other contextual learning projects at the Museum?

- Is the Learning Experience Model applicable for practicing teachers?

- Could the Learning Experience Model be applied to contextual learning projects at Victorian Specialist Science Centres, such as the Gene Technology Access Centre (GTAC), the Victorian Space Science Education Centre (VSSEC) or Quantum Victoria?

- Did the pre-service teachers increase their content knowledge of Geoscience? 


\section{References}

Andreas, S. (2011). International Summit on the Teaching Profession Building a High-Quality Teaching Profession Lessons from around the World: Lessons from around the World (Vol. 2011). OECD publishing.

Australian Curriculum, Assessment and Reporting Authority (ACARA) (2012). National Curriculum: Science, Retrieved from http://www.australiancurriculum.edu.au/science/curriculum/f-10?layout=1 Australian Curriculum, Assessment and Reporting Authority (ACARA) (2014a). Foundation to Year 10 Curriculum: Science (ACSSU153). from http://www.australiancurriculum.edu.au/science/curriculum/f-10?layout=1 - level8

Australian Curriculum, Assessment and Reporting Authority (ACARA) (2014b). Foundation to Year 10 Curriculum: Science (ACSSU180). from http://www.australiancurriculum.edu.au/science/curriculum/f-10?layout=1 - level9

Anderson, D., Lawson, B., \& Mayer-Smith, J. (2006). Investigating the impact of a practicum experience in an aquarium on pre-service teachers. Teaching Education, 17(4), 341-353.

Avraamidou, L. (2014). Developing a reform-minded science teaching identity: The role of informal science environments. Journal of Science Teacher Education, 25(7), 823-843.

Baker, V. R. (1996). The geological approach to understanding the environment. GSA Today, 6(3), 4143.

Barba, R. H., \& Rubba, P. A. (1993). Expert and novice, earth and space science: teachers' declarative, procedural and structural knowledge. International Journal of Science Education, 15(3), 273-282.

Blank, L. M., Plautz, M., Almquist, H., Crews, J., \& Estrada, J. (2012). Using Google Earth to Teach Plate Tectonics and Science Explanations. Science Scope, 35(9), 41-48.

Boyatzis, R. E. (1998). Transforming qualitative information: thematic analysis and code development. Thousand Oaks, CA : Sage Publications, c1998.

Author, (2015) [[details removed for peer review].

Dawkins, K. R., \& Dickerson, D. L. (2007). Building a community of teacher learners in an Earth/environmental science professional development opportunity. Journal of Geoscience Education, 55(1), 67.

Dekkers, J., \& De Laeter, J. R. (1997). The changing nature of upper secondary school science subject enrolments. Australian Science Teachers Journal, 43(4), 35.

Driver, R., Squires, A., Rushworth, P., \& Wood-Robinson, V. (1994). Chapter 14: Rocks Making sense of secondary science : research into children's ideas (pp. $x, 210$ p.). London; New York: Routledge.

European Commission (2004). Europe needs more scientists: Report by the High Level Group on Increasing Human Resources for Science and Technology in Europe. Luxembourg: Office for Official Publications of the European Communities.

Feig, A. D. (2010). An online introductory physical geology laboratory: From concept to outcome. Geosphere, 6(6), 942-951. 
Francek, M. (2013). A Compilation and Review of over 500 Geoscience Misconceptions. International Journal of Science Education, 35(1), 31-64.

Giorgis, S. (2015). Google Earth Mapping Exercises for Structural Geology Students-A Promising Intervention for Improving Penetrative Visualization Ability. Journal of Geoscience Education, 63(2), 140-146.

Goldsmith, D. W. (2011). A case-based curriculum for introductory geology. Journal of Geoscience Education, 59(3), 119-125.

Goodrum, D., Hackling, M., \& Rennie, L. (2001). Research Report: The status and quality of teaching and learning of science in Australian schools. Canberra; Department of Education, Training and Youth Affairs. Retrieved from

http://www.dest.gov.au/sectors/school education/publications resources/profiles/status and quli ty of science schools.htm.

Gupta, P., \& Adams, J. D. (2012). Museum-University Partnerships for Preservice Science Education Second international handbook of science education (pp. 1147-1162): Springer.

Harris, K. L., Jensz, F., \& Baldwin, G. (2005). Who's teaching Science: Meeting the demand for qualified science teachers in Australian secondary schools.

Hagevik, R. A. (2011). Five steps to success: Implementing Geospatial Technologies in the science classroom. Journal of Curriculum and Instruction, 5(1), 34-53.

Houseal, A. K., Abd-El-Khalick, F., \& Destefano, L. (2014). Impact of a student-teacher-scientist partnership on students' and teachers' content knowledge, attitudes toward science, and pedagogical practices. Journal of Research in Science Teaching, 51(1), 84-115.

Jung, M. L., \& Tonso, K. L. (2006). Elementary preservice teachers learning to teach science in science museums and nature centers: A novel program's impact on science knowledge, science pedagogy, and confidence teaching. Journal of Elementary Science Education, 18(1), 15-31.

Kali, Y. (2003). A virtual journey within the rock-cycle: a software kit for the development of systemsthinking in the context of the Earth's crust. Journal of Geoscience Education, 51(2), 165-170.

Kennelly, P. J. (2009). An online social networking approach to reinforce learning of rocks and minerals. Journal of Geoscience Education, 57(1), 33-40.

Kesidou, S., \& Roseman, J. E. (2002). How well do middle school science programs measure up? Findings from Project 2061's curriculum review. Journal of Research in Science Teaching, 39(6), $522-$ 549.

King, C. (2000). The Earth's Mantle Is Solid: Teachers' Misconceptions About the Earth and Plate Tectonics. School Science Review, 82(298), 57-64.

King, C. (2008). Geoscience education: An overview. Studies in Science Education, 44(2), 187-222.

King, C. (2010). An Analysis of Misconceptions in Science Textbooks: Earth Science in England and Wales. International Journal of Science Education, 32(5), 565-601.

King, C. (2012). Common Earth Science Misconceptions in Science Teaching. School Science Review(347), 45-52. 
King, C. (2013). Geoscience education across the globe-results of the IUGS-COGE/IGEO survey. Episodes, 36(1), 19-30.

King, C. (2015). The international geoscience school syllabus and its development. Episodes, 38(1), 57-74.

King, C., Kennett, P., \& Devon, E. (2013). Earthlearningidea: A worldwide web-based resource of simple but effective teaching activities. Journal of Geoscience Education, 61(1), 37-52.

Kisiel, J. (2013). Introducing future teachers to science beyond the classroom. Journal of Science Teacher Education, 24(1), 67-91.

Lewis, E. B. (2008). Content is Not Enough: A History of Secondary Earth Science Teacher Preparation with Recommendations for Today. Journal of Geoscience Education, 56(5), 445-455.

Lewis, E. B., \& Baker, D. R. (2010). A call for a new geoscience education research agenda. Journal of Research in Science Teaching, 47(2), 121-129. doi: 10.1002/tea.20320

Lyons, T. (2005). Different countries, same science classes: Students" experiences of school science in their own words. International Journal of Science Education, 28(6), 591-614.

Marques, L., Praia, J. o., \& Kempa, R. (2003). A study of students' perceptions of the organisation and effectiveness of fieldwork in earth sciences education. Research in Science \& Technological Education, 21(2), 265-278.

Orion, N., \& Thompson, D. B. (1996). Changes in perceptions and attitudes of pre-service postgraduate secondary school science teachers. International Journal of Science Education, 18(5), 577599.

Ratinen, I., \& Keinonen, T. (2011). Student-teachers' use of Google Earth in problem-based geology learning. International Research in Geographical \& Environmental Education, 20(4), 345-358. doi: 10.1080/10382046.2011.619811

Sadler, T. D., Burgin, S., McKinney, L., \& Ponjuan, L. (2010). Learning science through research apprenticeships: A critical review of the literature. Journal of Research in Science Teaching, 47(3), 235-256.

Schifman, L., Cardace, D., Kortz, K., Saul, K., Gilfert, A., Veeger, A. I., \& Murray, D. P. (2013). Sleuthing Through the Rock Cycle: An Online Guided Inquiry Tool for Middle and High School Geoscience Education. Journal of Geoscience Education, 61(3), 268-279.

Stocklmayer, S. M., Rennie, L. J., \& Gilbert, J. K. (2010). The roles of the formal and informal sectors in the provision of effective science education. Studies in Science Education, 46(1), 1-44.

Tran, L. U. (2007). Teaching science in museums: The pedagogy and goals of museum educators. Science Education, 91(2), 278-297.

Tytler, R (2007). Re-imagining Science Education: Engaging students in science for Australia's future. Australian Education Review No. 51. Australian Council for Education Research, ACER press.

Retrieved from www.acer.edu.au/research reports/AER.html

Vallender, G. D. (2010). Geological Science Education and Conceptual Change. (Doctor of Philosophy), Curtin University of Technology. 
Varelas, M., House, R., \& Wenzel, S. (2005). Beginning teachers immersed into science: Scientist and science teacher identities. Science Education, 89(3), 492-516.

VCAA. (2015a). Comparing VELS Science to AC Science 7-8. Retrieved September 14, 2015, from http://www.vcaa.vic.edu.au/Documents/auscurric/comparison/Comparing VELS Science to AC SC ience 3-6.pdf

VCAA. (2015b). Comparing VELS Science to AC Science 9-10. Retrieved September 14, 2015, from http://www.vcaa.vic.edu.au/Documents/auscurric/comparison/Comparing VELS Science to AC SC ience 9-10.pdf

VCAA (2016). The Victorian Curriculum F-10 curriculum. Retrieved September 11, 2016, from http://victoriancurriculum.vcaa.vic.edu.au/science/introduction/scope-and-sequence

Wallace, C. S. (2013). Promoting shifts in preservice science teachers' thinking through teaching and action research in informal science settings. Journal of Science Teacher Education, 24(5), 811-832.

Weldon, Paul R. (March 2015). The Teacher workforce in Australia: Supply, demand and data issues Policy Insights, Issue 2. Melbourne: ACER.

http://www.pc.gov.au/ data/assets/pdf file/0018/114912/government-services-2012volume1.pdf 


\section{Appendix A}

\section{Reconceptualising Rocks - Expression of Interest (The University of Melbourne)}

Improving the competence and confidence in the teaching of Earth Science for pre-service teachers. A Deakin University, University of Melbourne, Museum Victoria partnership project

In Semester 1 this 3 day Geology workshop is open to students who are enrolled in two Science Learning Areas. It will be a commitment of three days; two days at Museum Victoria and a one day excursion to Phillip Island. Involvement in this workshop will exempt you from attending any other workshops in Semester 1 (unless you really wish to attend).

Please complete the questions below.

Name:

Science Learning Areas:

Previous experience/learning in Geology and Earth Sciences:

Why do you wish to enrol for this workshop?

What do you hope to achieve through your participation in this workshop? 


\section{Appendix B}

\section{ReMSTEP Outcomes}

1. Evidence-based development of approaches to mathematics and science education and teacher education that link contemporary practices in the sciences to evidence-based, inquirybased, problem solving pedagogies consistent with contemporary thinking represented by the AITSL standards.

2. Improved visibility of teaching as a career option for high calibre science students, active promotion of postgraduate teacher education programs to these students, and improved support structures for these students as they progress through their course and into teaching full-time.

3. A cohort of graduate primary and secondary teachers better-equipped to integrate not just an awareness of contemporary mathematics and science concepts but aspects of actual mathematical and scientific practice into their classroom pedagogy.

4. Comprehensively documented innovative pedagogies that are specific to the education and communication of cutting edge mathematical and scientific practices, implemented across a variety of education contexts and sites.

5. Re-conceptualised units of study and science and mathematics educational activities that exemplify scientific practices, together with an evidence-based framework supported by public access resources to support collaborative work between specialist mathematics and science teacher educators and research mathematicians and scientists. Units and pedagogies will reflect the contemporary cross-disciplinary practices of scientific and mathematical knowledge generation and will align AITSL standards. It is anticipated that these will be made widely available through a web-mediated environment.

6. Innovative and effective teacher education practices that can be articulated and disseminated as exemplifications of meaning collaboration between the mathematics and science research communities and educators.

7. Key principles around which effective dissemination of these approaches can inform practice of other universities in connecting the sciences and teacher education together with communication principles and practices that can support public understanding of contemporary scientific practices and ideas.

8. An established network of science, mathematics and education researchers, supported with an online environment, dedicated to connecting contemporary science and mathematics and associated pedagogies in a variety of educational contexts (including low SES, high NESB, rural, remote, indigenous). 